\title{
Eleanor McDowell
}

John Ogilvie: A Jesuit in Disguise (1579-1615). London: Catholic Truth Society, 2015, Pp. 64. $\mathrm{Pb}, £ 2.50$.

Four hundred years have elapsed since the Jesuit John Ogilvie was hanged at Glasgow Cross in Glasgow. As Scotland's only post-Reformation saint and martyr, the country's Catholic and scholarly communities held a number of commemorative events to mark the quatercentenary of Ogilvie's martyrdom, including a well-attended conference entitled "John Ogilvie and the Jesuit Legacy and Scotland," shortly to be published as an edited collection, a special Mass in St Andrew's Cathedral in Glasgow attended by the papal envoy Cardinal Cormac Murphy-O'Connor, and a special concert at which music by the renowned composer James McMillan was performed. The small booklet under review formed part of these commemorations.

Published as it is by the Catholic Truth Society, whose aim is to "nurture" and "support" the "Christian life," John Ogilvie: A Jesuit in Disguise (1579-1615) is sympathetic to its subject and intended more as an aid to faith than as a scholarly, critical and impartial biography of Ogilvie. In this sense, the booklet may well be considered a success for it does provide an accessible and largely popular account of Ogilvie's life and times. By the same logic, it would be rather unfair to the booklet's author to review it without keeping in mind the spirit in, and the reason for, which it was written.

Divided into ten short chapters, the author moves chronologically from the Scottish Reformation through to Ogilvie's canonization in 1976 by Pope Paul VI. The first five or so chapters give a sweeping overview of the political and religious context of the Reformation period and Ogilvie's early life-his parentage, education on the European Continent, and his decision to join the Jesuits. The second half of the volume focuses, by and large, on Ogilvie's capture, trial, martyrdom, and the background to his canonization. This focus is understandable given the booklet's aim to be an aid to faith and what appears to be the author's personal devotion to the saint: Ogilvie's suffering for the faith is surely recounted to inspire and move the already faithful. As such, the author-perhaps with her overall purpose in mind - does not really engage with recent scholarship on Ogilvie. Yet, while keeping her purpose in mind, a more balanced presentation of the saint would have been useful in not only exposing readers to different interpretations-both then and now-of Ogilvie's mission and death, but also in avoiding slippages into hagiography: one can be sympathetic to a topic without being unduly reverential.

Of particular interest to this reviewer, given my own interests in Catholicism in modern Scotland, are the last two chapters, which deal with the events lead- 
ing up to Ogilvie's canonization. John Fagan, a middle-aged docker from Easterhouse in Glasgow, is well known to Catholics in Scotland and beyond as the man whose inexplicable recovery from cancer was attributed to Ogilvie's intervention. Fagan lived until 1993, dying at the respectable age of seventynine. Although clearly beyond the author's aims, Fagan's "miraculous" cure and Ogilvie's subsequent raising to the altar nevertheless pose a number of interesting questions about Catholicism in modern Scotland, particularly about the Catholic community's devotional life and practice. A study which explores these facets of Scottish Catholicism in the second half of the twentieth century, considering particularly the influence of the Second Vatican Council, would be very welcome indeed.

While, again, the booklet is not intended to be an academic publication, one thing in particular nags a little - the lack of references. Of course, references, particularly footnotes, may be something of a nuisance for the general reader and can, especially if overused, lead to something of an information "overload," but acknowledgement of the sources, especially the long primary source quotations, would have been useful; readers keen to learn more may want to revert to the original sources for more information. Similarly, while the booklet does have some images, more would have been useful given its popular focus.

This little volume will undoubtedly be of use and interest to general readers curious about John Ogilvie, perhaps in particular to Scottish (and more widely British) Catholics and those who have a relationship with the Society to which Ogilvie belonged. While the volume may not add anything new to our current understanding of Ogilvie - his life, mission, and death-the author has, I believe, met her publisher's aims and this work may introduce Scotland's only post-Reformation saint and martyr to a larger audience, which is surely a positive.

\section{Darren Tierney}

University of Glasgow darren.tierney@glasgow.ac.uk 